\title{
Jak je možná svobodná volba v deterministickém světě
}

\author{
Vít Punčochář \\ Filosofický ústav \\ Akademie věd České republiky \\ Jilská 1, 11000 Praha \\ puncochar@flu.cas.cz
}

V tomto článku předkládám některé důvody proti Dvořákovu nedeterministickému pojetí svobodné vůle, které vyložil ve své nedávno publikované knize Kauzalita činitele. Zejména se zabývám Dvořákovým řešením problému náhody, podle kterého je akt svobodné vůle náhodný do té míry, do jaké se nepodřizuje deterministickým zákonům, a do této míry také nemůže být předmětem morálního hodnocení. Proti Dvořákově koncepci stavím vlastní pojetí svobodné vůle, které je variací na to, co Dvořák označuje jako „standardní teorie“. Z hlediska tohoto pojetí je svobodná vưle možná i v deterministickém světě. Analyzuji, v čem spočívá volba mezi alternativními možnostmi, a argumentuji, že je možné mít kontrolu nad vlastním jednáním, i když nemáme kontrolu nad minulostí, která toto jednání jednoznačně determinuje. Zároveň vysvětluji, proč se v ostrém rozporu s Dvořákovou koncepcí domnívám, že člověk v deterministickém světě může nést odpovědnost za své činy.

Klíčová slova: svobodná vůle, Petr Dvořák, náhoda, kontrola, morální odpovědnost

\section{1. Úvod}

S ohledem na to, jak bohatá je produkce českých filosofických textů, je překvapující, že poměrně málo prostoru je $\mathrm{v}$ těchto textech věnováno jednomu z centrálních témat filosofie, které je tradiční a zároveň stále živé, totiž problému svobodné vůle. Na toto téma bylo v posledních desetiletích publikováno neuvěřitelné množství anglicky psané literatury, v našem prostředí se však této problematice mnoho lidí nevěnuje. 
Dvořákova kniha Kauzalita činitele ${ }^{1}$ je do jisté míry výjimkou. Je to pozoruhodný text, který se vyznačuje důkladností a dobrým přehledem o relevantní literatuře. Představuje a obhajuje svébytnou variantu jednoho z nejvýraznějších názorových proudů v debatě o svobodné vůli. Základním charakteristickým rysem tohoto přístupu je teze, že člověk je obdařen svobodnou vưlí, která je nutnou podmínkou morální odpovědnosti a je neslučitelná s deterministickým výkladem světa. ${ }^{2}$

V článku „Problém svobodné vůle a logika kontrafaktuálních výroků“3 jsem rozpracoval své pojetí jiného ze základních trendů filosofie svobodné vůle. ${ }^{4}$ Také podle tohoto přístupu je člověk obdařen svobodnou vůlí, ta je však naprosto slučitelná s determinismem, který není nikterak na překážku morální odpovědnosti. V chápání toho, v čem svobodná vůle a morální odpovědnost spočívají, jsou tedy tyto dva př́istupy ve vzájemné opozici. Velmi vítám tuto př́ležitost názorového střetu, o to více, že můj článek i Dvořákova kniha vycházejí z analytické tradice, a je zde tedy šance, že sdílíme základní argumentační principy.

\section{Základní rysy Dvořákova pojetí svobodné vůle}

Pokusím se nyní co nejpřesněji shrnout,jak rozumím Dvořákovu přístupu. Svobodná vůle je kapacita činit svobodná rozhodnutí a v důsledku toho svobodně jednat. Svobodné jednání není nic jiného než jednání determinované svobodným rozhodnutím. Klíčovou otázkou tedy je, v čem spočívá svobodné rozhodnutí. Člověk se rozhoduje mezi určitými alternativami. Pokud se pro něco rozhodne, je (podle Dvořákova pojetí) toto rozhodnutí svobodné pouze tehdy, když se v přesně té samé situaci a za zcela stejných vnitřních i vnějších podmínek mohl rozhodnout pro něco jiného. Jednání je pak svobodné, když rozhodující se subjekt (Dvořák používá termín „činitel“) měl možnost rozhodnout se a následně

1 Dvořák (2020).

2 Dvořákův př́istup je inspirován především Pinkem (např. 2003, 2016, 2019) a O’Connorem (např. 2000a, 2000b, 2005), avšak Dvořák i k těmto autorům přistupuje kriticky a vytváří svoji vlastní originální koncepci.

3 Punčochář (2017).

4 Toto pojetí má mnoho společného s tím, co Dvořák nazývá „standardní teorie“. Tato teorie byla v moderní verzi formulována Davidsonem (1980), avšak své kořeny má už u Hobbese (1651) a Huma (1748). Můj článek byl nejvýrazněji inspirován Moorem (1912). 
jednat jinak. Jen tak může být člověk za své rozhodnutí a následně za své jednání morálně odpovědný.

\begin{abstract}
„Aby mravní kvalifikace skutku byla možná, musí být příslušná osoba, jíž říkáme činitel, vlastním původcem jednání ve smyslu alespoň nutné podmínky jeho vzniku a toto jednání musí být působeno tak, že činitel mohl za daných okolností způsobit i něco jiného, než působí, nebo nezpůsobit vůbec nic.“5
\end{abstract}

Toto pojetí svobody podle Dvořáka koresponduje s běžnými intuicemi, které se odrážejí v právu a morálce. Připsat někomu odpovědnost můžeme smysluplně pouze tehdy, když jeho jednání nebylo důsledkem okolností, nad nimiž neměl kontrolu. Svobodný subjekt musí být schopen determinovat sám sebe - tato determinace nemůže být působena něčím od něj odlišným.

Pokud by byl člověk ke svému jednání determinován něčím, co nemá pod vlastní kontrolou, znamenalo by to, že neměl možnost jednak jinak, než jak ve skutečnosti jednal. On sám a nic jiného musí být zdrojem intence jednat určitým způsobem.

Je-li nutnou podmínkou svobody možnost jednat - za přesně stejných vnitřních a vnějších podmínek - různými způsoby, znamená to, že ve vztahu k fixně dané minulosti existuje více možných budoucností. To je však přesně negace deterministického pojetí světa, $v$ němž minulost jednoznačně určuje jedinou možnou budoucnost. $\mathrm{Z}$ toho, že máme svobodnou vůli, kterou přímo zakoušíme $\mathrm{v}$ každodenní zkušenosti, můžeme usoudit, že svět je nedeterministický.

„... nutnou podmínkou toho, aby jednání bylo svobodné, je možnost nekonat to, co se koná, možnost učinit opak. V okamžiku bezprostředně před rozhodnutím či konáním existuje ve vztahu k dané minulosti vícero možných budoucností, tj. neexistuje jediná událost, která se uskuteční.

5 Dvořák (2020, s. 17-18). 
Takže se zdá být zřejmé, že svoboda jednání není slučitelná s tím, aby jednání bylo výsledkem deterministického působení. Proto, vyskytne-li se alespoň jedno svobodné jednání, nemůže skutečnost existovat tak, jak tvrdí determinismus. Jinými slovy, determinismus musí být nepravdivý.“ ${ }^{6}$

\section{Problém náhody}

Proti tomuto pojetí svobody existuje standardní námitka. ${ }^{7}$ Je-li rozhodování člověka nedeterministické, znamená to, že nelze uvést nic, co by určovalo, že se v dané chvíli rozhodl pro možnost $\mathrm{X}$ a nikoli pro možnost Y, nebot' obě tyto varianty mohly nastat za zcela totožných okolností - to znamená: nejen v identických vnějších podmínkách, ale i při zachování stejných kognitivních a charakterových vlastností rozhodujícího se subjektu, v kontextu stejných přesvědčení a téže vnitřní motivace. Pak to ale vypadá, že výsledek rozhodnutí, k němuž reálně došlo, je určen pouhou náhodou, která je však se svobodou neslučitelná.

Dvořák se domnívá, že tato námitka je neoprávněná. V této souvislosti rozlišuje mezi determinujícím faktorem, který kauzálně určuje charakter účinku, a deterministickým faktorem, na jehož základě lze dedukovat, že daný účinek nastane. Dále rozlišuje mezi náhodným a nahodilým. Událost je náhodná, když pro ni chybí determinující faktory. Podle Dvořáka však mohou existovat nedeterministické determinující př́činy. Je-li př́íčina nedeterministická, je její účinek nahodilý v tom smyslu, že mohl nastat i jiný účinek. Jinými slovy, účinek nelze předem z př́činy odvodit. Avšak pokud nedeterministická prř́čina determinuje plně všechny aspekty svého účinku, nelze tento účinek pokládat za náhodný. K této specifické kauzalitě dochází v procesu svobodného rozhodování. Člověk při něm determinuje zcela své jednání, které tak není výsledkem náhodného procesu. Jednání je však determinováno nedeterministickým způsobem, a proto je svobodné. Dvořák v této souvislosti mluví o nedeterministické kontingentní determinaci.

6 Tamtéž, s. 25 .

7 Tato námitka je formulována např. u Ayera (1954) či Meleho (2006). 
„,... i když absentují deterministické faktory (kauzální či nekauzální), mohou existovat nedeterministické determinující faktory, nedeterministické prŕččiny. Nakolik nedeterministická př́íčina nedeterminuje všechny aspekty účinku, ale jen některé, lze hovořit o náhodnosti... Pokud však nedeterministická prř́čina determinuje účinek plně, tj. všechny jeho aspekty, pak taková determinace náhodu na této rovině determinace vylučuje. Činitel determinuje všechny aspekty svého jednání. Proto zde nelze hovořit o náhodě.“8

Tato argumentace, nakolik jí rozumím, mi připadá problematická. Co se míní tím, že výsledek nedeterministického rozhodnutí je určen pouhou náhodou? Náhoda neznamená nic víc než absenci jakéhokoli zdroje vysvětlení. Otázka, zda je výsledek rozhodování náhodný, tak odpovídá otázce, zda je v principu možné vysvětlit, proč $\mathrm{k}$ tomuto rozhodnutí došlo. Běžně vysvětlujeme určité rozhodnutí či jednání na základě motivů. Např́klad rozhodne-li se někdo nevzít nabízený úplatek, může to být třeba ze strachu před př́padným odhalením nebo proto, že je v něm silně zakořeněné přesvědčení, že braní úplatků je morálně nepřijatelné. V typickém prŕpadě jde o kombinaci řady takovýchto motivů, které převážily nad přáním získat jednoduchým způsobem peníze. Avšak vysvětlení určitého jednání na základě motivio je neslučitelné s pojetím svobody, které Dvořák ve své knize zastává. Aby se člověk rozhodoval svobodně, nesmí jeho morální a jiná přesvědčení, ani jeho přání a tužby jednoznačným způsobem determinovat výsledek rozhodnutí.

Při tomto pojetí svobody tedy principiálně přicházíme o významný způsob vysvětlení daného rozhodnutí. Pokud není tento způsob vysvětlení nahrazen nějakým jiným, zůstává rozhodnutí nevysvětleno, a právě v tomto smyslu je náhodné.

Dvořákovo řešení tohoto problému se tedy dá shrnout takto. Námitka, o kterou jde, zní: výsledek nedeterministického procesu je náhodný a jako takový není v souladu se svobodou. Podle Dvořákovy interpretace náhodnost $\mathrm{v}$ této námitce znamená, že výsledek nedeterministického procesu nemá příčinu. Námitku řeší tak, že postuluje možnost nede-

8 Dvořák (2020, s. 31). 
terministických, avšak plně determinujících příčin. V případě výsledku rozhodnutí je takovou prríčinou přímo rozhodující se činitel. Moje reakce na toto řešení pak spočívá v tvrzení, že v původní námitce není ani tak podstatné, zda má výsledek nedeterministického procesu příčinu, ale spíše to, že takový výsledek nelze ničím vysvětlit. Příčina zde figuruje do té míry, že se jedná o typický nástroj vysvětlení. Domnívám se, že postulování nedeterministické determinující příčiny nijak nevysvětluje, proč k danému rozhodnutí došlo, a problém tedy zůstává.

Proč nedeterministická determinující př́čina nemůže sloužit jako do̊vod vysvětlující vznik nějaké události? Abychom mohli A považovat za důvod dostatečně vysvětlující $\mathrm{B}$, musí A nějakým způsobem implikovat $\mathrm{B}$, což znamená, že když zafixujeme relevantní okolnosti, a přitom platí A, s určitou mírou nutnosti musí platit i B. Důvod samozřejmě nemusí mít vždy podobu příčiny, jako ho nemá například matematické zdơvodnění, ale vždy by měl mít za daných okolností charakter postačující podmínky. Avšak Dvořák vymezuje pojem nedeterministické příčiny - v protikladu k deterministické příčině - právě jako takové př́ičiny, ze které účinek nelze nijak odvodit. Domnívám se tedy, že důvod nemůže mít podobu nedeterministické determinující př́ičiny právě proto, že na ní nelze identifikovat nic, co by vylučovalo jiný výsledek než ten, který reálně nastal a který má být vysvětlen.

Sice v současné době máme dobré doklady toho, že teorie operující s nedeterministickou kauzalitou může být velmi užitečná a dobře použitelná k pravděpodobnostním predikcím, avšak to, jestli jsou v takové teorii příčiny pokládány za plně determinující či nikoli, nemůže mít na predikovatelnost žádný vliv. Co se nachází za hranicí predikovatelnosti, zůstává teorií nevysvětleno. Pokud nedeterministická teorie na základě daných vstupních podmínek připouští X a Y jako dva stejně možné výstupní stavy, nemůžeme tuto teorii použít pro vysvětlení toho, proč ve skutečnosti došlo $\mathrm{k} \mathrm{X}$ a nikoli $\mathrm{k} \mathrm{Y}$, a nepomůžeme si příliš ani tehdy, když v rámci této teorie označíme příčiny za plně determinující, i když nikoli deterministické.

Má nedůvěra $\mathrm{k}$ pojmu nedeterministické, avšak plně determinující př́ičiny je tedy dána tím, že tento pojem postrádá charakteristické instrumentální vlastnosti standardních kauzálních pojmů. Podstatným rysem kauzality je, že př́ičiny mohou sloužit jako do̊vody a kauzální vzta- 
hy umožňují predikci. Pojem nedeterministické determinující př́íčiny neumožňuje ani jedno z toho. Na otázku, proč se činitel rozhodl nevzít nabízený úplatek, nelze uvést nic, zakážeme-li si poukazovat na motivy či jakékoli jiné vlastnosti činitele.

Dvořák si je nepochybně vědom této potenciální výhrady. V tomto kontextu podniká následující argumentační manévr. K vysvětlení nedeterministické determinující kauzality svobodného rozhodnutí použíá aristotelský pojem finální příčiny. Normativní vlastnosti cíle působí jako finální př́čina. Cíl klade nárok na člověka a ten ho rozpoznává svým rozumem. Cíl sám může figurovat jako vysvětlující faktor pro dané rozhodnutí. Náš činitel se rozhodnul nevzít úplatek, protože takové jednání je správné.

\begin{abstract}
„Bud’ fakt, zda se v jednotlivé situaci realizuje A nebo B, závisí na činiteli, nebo nezávisí... Co v tomto případě znamená „závisí na činiteli“? Jednání vychází z cíle, k jehož realizaci má vést.“9
\end{abstract}

Ale není přece jen pro finální rozhodnutí podstatné, jak je sám činitel citlivý vůči normativním vlastnostem cíle, a není tato citlivost součástí vnitřního nastavení jedince, které spoluutváří vstupní kauzální podmínky v situaci rozhodování? Na tuto námitku Dvořák reaguje, když se vymezuje proti Davidsonově „standardní teorii“, v níž se svobodné jednání nevysvětluje na základě cíle samotného, nýbrž kauzálně, na základě mentálních stavio, které jsou na tento cíl zaměřeny. Dvořák tvrdí, že cíl je vzhledem k motivům primární:

„Tento motiv, mentální stav, je ale zajisté druhotný. Touha po dosažení věcného stavu je zde proto, že cíl, věcný stav, má určité normativní charakteristiky vyvolávající touhu, a nikoli naopak. Jednání v této [„standardní“] teorii lze specifikovat bez odkazu k cíli. Alternativou je chápat jednání jako bytostně zacílené. Chůze by tak nebyla sama o sobě jednáním, nýbrž jen chůze vztažená $k$ cíli.“"10

\footnotetext{
9 Tamtéž, s. 32.

10 Tamtéž, s. 135.
} 
Avšak může cíl za těchto okolností figurovat jako důvod vysvětlující dané rozhodnutí? Domnívám se, že nikoli, a to ve stejném smyslu, v jakém takto nemůže figurovat nedeterministická příčina. Cíl sám nemůže být dostatečným vysvětlením daného jednání, když za zcela stejných podmínek a při zcela stejném působení cíle by mohlo dojít i k jinému rozhodnutí a následně k jinému jednání. Cíl sám - bez vhodného motivačního nastavení subjektu a jeho citlivosti vzhledem $\mathrm{k}$ cíli - nijak dané rozhodnutí neimplikuje, a tedy ani nevysvětluje.

Je patrné, že Dvořák si je těchto potenciálních problémů vědom a pečlivě je promýšlí. Avšak musím se přiznat, že mi jeho řešení nepřipadá přesvědčivé. V této souvislosti dokonce jakoby sám na chvíli připouští, že výsledek takto pojatého svobodného rozhodnutí je výsledkem náhodným, čímž by ovšem celá reakce na výchozí námitku byla bez řešení smetena ze stolu:

„U rozhodnutí pro jednání (a pro cíl, k němuž jednání vede) nelze udat důvod, který by předem vyloučil ostatní cíle a jiná jednání. Kdyby tomu tak bylo, pak by motivy, tj. nahlédnutelný cíl s jeho normativními charakteristikami (proč jej preferovat), a nahlédnuté jednání k němu vedoucí samy působily jako deterministické faktory určující činitelovo rozhodnutí a následné jednání. Proč se činitel tedy rozhodl pro tento cíl a ne jiný? Je to náhoda? Pokud je, pak ovšem ne taková, jež by bránila v kontrole nad jednáním, protože činitel sám se rozhoduje pro daný cíl a jednání, které předem poznává, třebaže neexistuje rozhodující důvod preferovat právě tento cíl a jednání, na jehož základě by se dalo s pravděpodobností 1 predikovat, že se takto rozhodne."

Domnívám se, že smysl praxe připisování odpovědnosti musí nějak vnitřně souviset s tím, co to vůbec znamená odpovědnost mít. Smysl praxe připisování odpovědnosti spočívá v tom, že formuje motivaci jedinců a skrze ni kauzálně působí na jejich jednání. Vědomí odpovědnosti za vlastní činy je pro nás silným kauzálním faktorem, který spolu s ostat-

11 Tamtéž, s. 33 . 
ními psychologickými faktory determinuje naše rozhodování. Avšak v nedeterministické teorii svobodného rozhodnutí jako by se skutečná morální odpovědnost jedince zcela míjela s touto funkcí, kterou má praxe připisování odpovědnosti. Vědomí odpovědnosti za výsledek rozhodnutí jakožto kauzální psychologický faktor totiž z principu nemůže mít vliv na nezdůvodnitelné a nemotivované aspekty rozhodnutí, které jsou podle této teorie klíčovou podmínkou existence svobodné vůle.

\section{Volba mezi alternativními možnostmi}

Zatímco nedeterministická teorie svobodného rozhodnutí se potýká s neodbytně se vnucujícím problémem náhody, její protipól, tj. deterministická teorie svobodného rozhodnutí, čelí jiné intuici, totiž silnému dojmu, že determinismus neumožňuje výběr z alternativních možností, který je nutným předpokladem svobodné volby. ${ }^{12}$ Tato intuice je skutečně velmi silná a nelze ji brát na lehkou váhu. Jak mohu být svobodný, když každé rozhodnutí, které v životě udělám, bylo jednoznačně determinováno ještě před tím, než jsem se narodil?

Nyní se pokusím vyložit vlastní řešení tohoto problému, ${ }^{13}$ které je silně inspirováno takzvanou kondicionální analýzou problému svobodné vůle mající kořeny u G. E. Moora ${ }^{14}$. Je pravda, že rozhodování spočívá ve výběru mezi alternativními možnostmi. Je také pravda, že pokud je proces rozhodování deterministický, pak z globálního kauzálního hlediska může nastat jen jedna z těchto alternativ. Avšak toto globální hledisko není hlediskem rozhodujícího se subjektu a ani jím z principu nemůže být. Pro subjekt nemůže být výsledek procesu rozhodování definitivně určen dřive, než tímto procesem projde. Znalost výsledného rozhodnutí by totiž byla sama faktorem, který by výsledek mohl zvrátit. Pokud bych věděl, že je definitivně předem určeno, že se rozhodnu jít doleva, a nikoli doprava, mohl bych se na základě této znalosti - čistě ze zlomyslné schválnosti - rozhodnout jít doprava. Je podstatným aspektem rozhodování, že z perspektivy rozhodujícího se subjektu představují alternativy,

12 To je společná teze inkompatibilistů, ke kterým se kromě Dvořáka řadí např. Robert Kane (1989, 2000) či van Inwagen $(1975,1983)$.

13 Toto řešení rozvádí základní myšlenky mého článku Punčochář (2017).

14 Moore (1912). 
mezi nimiž se rozhoduje, zcela otevřené možnosti. A pro tuto perspektivu, která je pro otázku svobody klíčová, je irelevantní, že z jiné perspektivy, totiž z perspektivy globální kauzality, je již předem rozhodnuto.

Řekněme, že se náš činitel rozhoduje, jestli si koupí drahé nebo levné auto. Má dostatek peněz, aby si mohl dovolit drahé auto, po kterém již dlouhou dobu touží, ale chce ještě realizovat rekonstrukci bytu a pokud si koupí drahé auto, na tuto rekonstrukci mu již nezbyde dostatek prostředků. Předpokládejme, že celý proces rozhodování je deterministický. Nicméně i tak má velmi dobrý a přirozený smysl říci, že je v situaci, kdy si může vybrat jakoukoli z těchto možností. Může si koupit drahé auto a může si koupit levné auto, a to v tom smyslu, že pokud se rozhodne koupit si drahé auto, koupí si drahé auto, pokud se však rozhodne koupit si levné auto, koupí si levné auto. Jinými slovy, to, jaké auto si ve výsledku koupí, závisí podstatně na jeho rozhodnutí. Je podstatnou složkou celého tohoto (deterministického) procesu rozhodování, že obě tyto možnosti jsou z perspektivy činitele oprávněně vnímány jako otevřené.

Člověk se nerozhoduje mezi alternativami, které jsou možné z nějakého absolutního metafyzického hlediska. Rozhoduje se mezi tím, co je závislé na jeho vůli, tedy mezi tím, co svým rozhodnutím může ovlivnit. Co je a není závislé na vưli rozhodujícího se subjektu, je objektivním faktem. Na mé vůli např́iklad závisí, zda si dnes vezmu šedou či modrou košili, ale nikoli to, jestli dnes dojde k zatmění slunce. Není pravda, že by dnes došlo k zatmění slunce, kdybych se pro to rozhodnul, avšak je objektivním faktem, že kdybych si vybral šedou košili, tak bych si ji také vzal. Pro jakou košili se ve výsledku rozhodnu, může být výsledkem deterministického procesu. Avšak ty možnosti, pro které jsem se ve skutečnosti nerozhodl, nelze pokládat za fiktivní jen proto, že nebyly v deterministickém procesu rozhodování vybrány. Sehrály svoji aktivní roli jako relevantní reálné možnosti, mezi kterými subjekt vybíral či mohl vybírat. I v deterministickém světě může mít rozhodující se subjekt realistický či nerealistický odhad toho, co může učinit, a skutečnost, jak realistický odhad v této věci má, podstatně ovlivňuje, jestli se rozhoduje správně.

Př́ičinou silné intuice, že determinismus neumožňuje svobodu, je, domnívám se, přirozená tendence směšovat perspektivu rozhodujícího 
se subjektu s globální perspektivou celku deterministické skutečnosti. Tvrdím, že tyto perspektivy mají odlišnou relevanci pro problém svobodné vưle.

Nejvíce problematickým důsledkem takového směšování perspektiv je smazání určitých elementárních praktických rozdílů, které mají své místo a musí být zachovány i v deterministickém světě. Pokud je determinismus překážkou svobodné vůle, nebot’ nedává subjektu prostor rozhodovat se mezi alternativními možnostmi, znamená to, že za předpokladu determinismu pro mě dnes byla možnost vzít si šedou košili stejně nedosažitelná jako možnost způsobit zatmění slunce (nebot’ jsem si šedou košili nakonec nevzal). To mi připadá jako absurdní závěr, nebot’ je holým faktem, že jsem se rozhodoval mezi šedou a modrou košilí a konstitutivním aspektem tohoto rozhodování bylo mé přesvědčení, že si mohu vzít šedou košili. Bylo snad toto přesvědčení iluzorní?

Ve specifických př́padech ovšem dává smysl říci, že přesvědčení o existenci nějaké možnosti v rámci procesu rozhodování bylo iluzorní. Někdy pokládáme za objektivní možnost něco, co ve skutečnosti objektivní možností není. Např́iklad se domnívám, že za stromem, který před sebou vidím u silnice, je odbočka doprava, a rozhoduji se, zda pojedu stále rovně, či odbočím. Avšak ve skutečnosti tam žádná odbočka není. V takové situaci bylo mé rozhodování v přirozeném smyslu slova založeno na iluzi, nebot neplatí, že bych odbočil po cestě doprava, kdybych se pro to rozhodnul. To je ale situace podstatně odlišná od př́ípadu s košilí, kde o takovéto iluzi nelze rozumně mluvit. A právě tato přirozená rozlišení, která ke své smysluplnosti nijak nevyžadují nedeterministickou realitu, svědčí proti tezi, že determinismus a svobodná vůle jsou neslučitelné.

I v deterministickém světě platí, že když je člověk přesvědčen, že jeho vůle není více než pasivním vykonavatelem toho, co je předem dáno, a tudíž nemůže reálně nic ovlivnit, bude jednat jinak, než když je přesvědčen o své svrchované roli v procesu rozhodování a o možnosti aktivně spoluurčovat, co se v budoucnosti stane. Přesvědčení o vlastní možnosti ovlivnit dění ve vnějším světě je podmínkou této možnosti. Avšak právě skutečnost, že toto přesvědčení je důležitým faktorem, který má faktický vliv na to, jak se člověk zachová, je dokladem jeho pravdivosti. I v deterministickém světě jednání člověka bytostně závisí na jeho vůli. 
Přesvědčení, že mám svobodnou vůli, potřebuji k tomu, abych se mohl v deterministickém světě aktivně rozhodovat. Toto přesvědčení není iluzí.

\section{Problém kontroly}

Avšak základní otázka se stále vnucuje a uznávám, že vnucovat se asi jen tak nepřestane: Jak může mít činitel kontrolu nad tím, co učiní a pro co se rozhodne, když v jistém smyslu je již vše dávno určeno? Souhlasím s tím, že aby byl subjekt svobodný, tak musí mít nad vlastním jednáním kontrolu. Avšak nesouhlasím s Dvořákovým pojetím kontroly založené na koncepci absolutní sebedeterminace. Přiznám se, že pojem absolutně sebedeterminujícího činitele není pro mě srozumitelný. Takový činitel sám sebe určuje, avšak nikoli na základě svého charakteru a osobnostních rysů, které jsou výslednicí interakce vrozených předpokladů a okolního působení. Mechanismus tohoto sebeurčování je tak pro mě zcela nejasný.

Je však možné mít kontrolu nad svým jednáním v deterministickém světě? Pro vyvrácení takové možnosti uvádí Dvořák ${ }^{15}$ slavný van Inwagenův argument, jehož jádro lze stručně shrnout takto: ${ }^{16}$ Mít kontrolu nad jednáním znamená mít kontrolu nad faktory, které jednání determinují. $\mathrm{V}$ deterministickém světě jsou z definice těmito faktory minulost a př́írodní zákony. Avšak činitel nemůže mít kontrolu ani nad minulostí, ani nad zákony př́rody. Tedy v deterministickém světě činitel nemůže mít kontrolu nad svým jednáním.

Ač zní tato argumentace velmi intuitivně, domnívám se, že obsahuje špatnou analýzu toho, v čem kontrola spočívá. Co znamená, že má člověk něco pod kontrolou? Nic víc než, že se to chová v souladu s jeho vưlí a že to může vůlí usměrňovat. Fotbalista má pod kontrolou míč, když se tento míč pohybuje směrem, který mu vůle hráče určuje. Fotbalista naopak míč pod kontrolou nemá, když mu třeba míč utíká, i když je záměrem hráče udržet ho u nohy, nebo když chce přihrát spoluhráči, ale míč letí k protihráči.

15 Dvořák (2020, s. 26-27).

16 Van Inwagenův argument lze najít v různých podobách v různých publikacích. V jedné verzi se vyskytuje např. ve van Inwagen (1975). 
V tomto smyslu můžeme mít pod kontrolou své jednání, i když nemůžeme vůlí nijak změnit minulost a přrírodní zákony. To, jestli na křižovatce odbočím doleva nebo doprava, mám pod kontrolou, protože z mé perspektivy řidiče jsou pravdivé tyto věty:

(1) Když se rozhodnu odbočit doleva, skutečně doleva odbočím.

(2) Když se rozhodnu odbočit doprava, skutečně doprava odbočím.

Z mé perspektivy řidiče, který se před křižovatkou rozhoduje, kam odbočit, jsou obě tyto možnosti otevřené, což je skutečnost, která spoluutváří situaci rozhodování. Předpokládejme, že se ve skutečnosti rozhodnu odbočit doleva, což je deterministickým důsledkem minulých stavů světa a přírodních zákonů. I tak bude stále pravda, že jsem mohl odbočit doprava, protože, kdybych se pro to rozhodnul, odbočil bych tam. Je ovšem také pravda, že kdybych se rozhodnul odbočit doprava, byla by minulost jiná, než jaká skutečně byla (předpokládejme, že přírodní zákony jsou fixovány). To ovšem neznamená, že kdybych se rozhodnul odbočit doprava, tak bych změnil minulost. $\mathrm{V}$ tomto smyslu mám pod kontrolou, kam odbočím, i když nemohu změnit minulost.

Matoucí na této úvaze je, že pokud ji přijmeme, jsme nuceni prohlásit, že závěr následujícího intuitivního argumentu nelze legitimně odvodit z jeho předpokladů, což se na první pohled zdá nesprávné:

Předpoklad 1. Mohu odbočit doleva.

Předpoklad 2. Kdybych odbočil doleva, byla by minulost jiná, než jaká ve skutečnosti je.

Závěr: Tedy mohu změnit minulost.

Ale tento argument je skutečně neplatný $\mathrm{v}$ tom ohledu, že předpoklady mohou být v jistém smyslu oba pravdivé, avšak to nijak negarantuje pravdivost závěru. Důvod je zcela analogický jako u následujícího argumentu, kde je to však zřetelněji vidět: 
Předpoklad 1. Je možné, že venku nyní prší.

Předpoklad 2. Kdyby venku nyní pršelo, bylo by tam jiné počasí, než jaké tam ve skutečnosti je.

Závěr: Tedy je možné, že venku je jiné počasí, než jaké tam ve skutečnosti je.

Řekněme, že první předpoklad je pravdivý z hlediska někoho, kdo je zavřený v místnosti bez oken a nemá výhled na ulici, a tudíž nevidí, jaké je venku právě počasí. Dále předpokládejme, že druhý předpoklad je pravdivý z toho důvodu, že venku ve skutečnosti nyní neprší. Je však zjevné, že z těchto dvou předpokladů nemůžeme odvodit uvedený závěr. Proč tomu tak je? U předpokladů došlo ke zjevnému posunu kontextu, vůči kterému pravdivost vyhodnocujeme. První předpoklad je pravdivý relativně vzhledem k situaci někoho zavřeného v domě, avšak druhý předpoklad je pravdivý vzhledem $\mathrm{k}$ jinému kontextu, který zahrnuje na rozdíl od toho prvního informaci, že venku ve skutečnosti neprší. Takové posuny kontextu bývají typickým důvodem toho, že nějaký úsudek vyznívá absurdně, i když má na první pohled platnou formu. Jako velmi odlišný ilustrativní př́klad, za jehož absurdností je však také jistý kontextový posun, můžeme uvést tento argument:

Předpoklad 1: Když si koupím auto, nebudu mít na nájem.

Předpoklad 2: Když vyhraju v loterii, koupím si auto.

Závěr: Tedy když vyhraju v loterii, nebudu mít na nájem.

První premisa mluví o tom, že když si za současné situace koupím auto, nebudu mít na nájem. $V$ druhé premise je však nákup auta podmíněn výhrou v loterii, čímž se posouváme do jiného kontextu. $V$ tomto a v předchozím argumentu je kontextový posun patrný. U argumentu se změněnou minulostí je kontextový posun hưře identifikovatelný, ale př́itomný je tam též. První premisa je pravdivá relativně vǔči kontextu rozhodujícího se řidiče, konkrétněji vzhledem k tomu, mezi čím se objektivně může v dané situaci smysluplně rozhodovat. Součástí tohoto kontextu není a ani z podstaty věci nemůže být úplná informace o minulosti, která determinuje řidičovo výsledné rozhodnutí. Avšak tato informace je součástí kontextu, vzhledem k němuž je pravdivý druhý předpoklad. Tyto kontexty se tedy liší. 


\section{Problém morální odpovědnosti}

Výrazným důvodem, proč Dvořák usiluje o teorii nedeterministické svobodné vůle, je jeho přesvědčení, že alternativní teorie svobodné vůle, jako je ta výše načrtnutá, neumožňují morální odpovědnost člověka za své činy. Jak mohu být odpovědný za něco, co bylo determinováno dřive, než jsem se narodil?

Jak jsem již naznačil, domnívám se, že hlavní funkcí pojmu odpovědnosti je to, že působí jako klíčový faktor v motivačním systému jedinců. ${ }^{17}$ Odpovědnost připisujeme sobě i druhým z dobrého důvodu. Je pozoruhodným faktem, že dává dobrý smysl připisovat odpovědnost člověku jen za to, co je předvídatelným důsledkem jeho rozhodnutí. Kdybychom začali systematicky připisovat lidem odpovědnost za děje na noční obloze, nemělo by to žádný důsledek na tyto děje. Avšak když systematicky připisujeme odpovědnost za předvídatelné důsledky lidských rozhodnutí, má to na tato rozhodnutí, a tedy i na jejich důsledky podstatný vliv.

Myšlenka, že jedinec $\mathrm{v}$ deterministickém světě nemůže nést za nic odpovědnost, zcela smazává právě popsaný rozdíl, nebot' podle této myšlenky v deterministickém světě nemá jedinec nad svým jednáním o nic větší kontrolu než nad pohybem nebeských těles. Tento důsledek považuji za nepřijatelný.

Jsem přesvědčen, že význam predikátu odpovědnosti musí vnitřně souviset s funkcí praxe připisování odpovědnosti. Jinými slovy, odpovědnost nepovažuji za nějakou nezávislou ontologickou kategorii, ale chápu ji jako něco, co bylo konstituováno příslušnou praxí používání tohoto predikátu. Tato praxe má poměrně jasně stanovenou funkci, která dává smysl i uvedenému predikátu.

Nést odpovědnost za své činy mimo jiné znamená právě to, že při morálním posuzování těchto činů bude kauzální řetěz událostí zpětně sledován jen k osobě činitele a původnější kauzální faktory, které tuto osobnost zformovaly, budou ignorovány. Avšak to neznamená, že takové původnější kauzální faktory neexistují. Je důležitým aspektem kauzálního uvažování, že sledujeme kauzální řetězce jen tam, kam má smysl, abychom je sledovali. Například při požáru chaty označíme za příčinu

17 Toto pojetí odpovědnosti je podrobněji vyloženo v Punčochář (2017) a navazuje např. na klasický text Moritze Schlicka (1939). 
výbuch propanbutanové plynové láhve a nikoli mnohem dřívější dědické řízení, které umožnilo podnikatelovi založit firmu, která tuto láhev vyrobila. Podobně při odsouzení vraha označíme za příčinu vraždy rozhodnutí vraha a nikoli události odehrávající se v jeho dětství. Avšak to, kam až je vhodné sledovat kauzální řetězec, se může měnit s kontextem. Jinou úlohu má při detekci prŕčciny vraždy soudce a jinou má psycholog, který následně s odsouzeným vrahem pracuje ve vězení.

Když připisujeme člověku odpovědnost za nějaký jeho čin, zastavíme se ve zpětném sledování kauzálního řetězce v momentě jeho rozhodnutí. Tato praxe má velmi dobrý smysl. Je však v kontrastu s tím, když mluvíme o determinismu a zvažujeme při tom na abstraktní úrovni kauzální řetězce v jejich úplnosti. Otázka slučitelnosti svobodné vůle s determinismem staví oba tyto fenomény na stejnou úroveň a tím nás přirozeně vede k ignorování rozdílu mezi odpovídajícími perspektivami. To způsobuje silný intuitivní sklon domnívat se, že svobodná volba v deterministickém světě není možná.

\section{Závěr}

Dvořákova kniha Kauzalita činitele reprezentuje významný proud v diskusi o svobodné vůli a rozpracovává originálním způsobem některé jeho aspekty. Podle tohoto myšlenkového směru je nutnou podmínkou možnosti existence svobodné vůle nedeterministický svět. Moji hlavní námitku proti tomuto pojetí, kterou jsem v tomto textu vyložil, lze shrnout takto: Přesvědčení, že svobodná vůle je neslučitelná s determinismem, vychází z toho, že svobodná vưle předpokládá variabilitu možností, mezi kterými subjekt svobodně volí, zatímco determinismus takovou variabilitu z definice nepřipouští. Domnívám se však, že v této úvaze dochází $\mathrm{k}$ neoprávněnému ztotožnění dvou zásadně odlišných perspektiv. Determinismus sice nepřipouští při fixně dané minulosti variabilitu možných budoucích událostí, avšak činí tak z globální ontické perspektivy. Naproti tomu prostor možností, mezi kterými činitel volí, musí být konstituován s přihlédnutím ke specifické perspektivě činitele, zejména k jeho epistemickému stavu. To neznamená, že takový prostor možných variant je čistě subjektivní. Naopak, o jeho objektivitě svědčí, že subjekt 
se může mýlit v tom, co je a co není reálnou možností, kterou by měl při rozhodování zvážit. I v deterministickém světě by bylo chybné domnívat se, že nyní mohu pouhou myšlenkou, tj. bez toho, abych se jakkoli pohnul, přemístit vzdálený fyzický předmět z jednoho místa na jiné, avšak není chybné být přesvědčen, že nyní mohu vstát a odejít. I v deterministickém světě totiž mé rozhodování povede k zásadně lepším výsledkům, když se budu rozhodovat na základě přesvědčení druhého typu a nikoli na základě přesvědčení prvního typu. Kdyby však svobodná vůle byla neslučitelná s determinismem, takové rozlišení mezi reálnými a nereálnými možnostmi by v deterministickém světě nedávalo dobrý smysl.

\section{Literatura}

Ayer, A. J. (1954): „Freedom and Necessity.“ In Philosophical Essays, A. J. Ayer, Macmillan, London.

Davidson, D. (1980): Essays on Actions and Events. Clarendon Press, Oxford.

Dvořák, P. (2020): Kauzalita činitele. Úvod do analytické diskuse o svobodě vưle. Togga, Praha.

Hobbes, T. (1651): Leviathan. Andrew Crooke, London.

Hume, D. (1748): An Enquiry Concerning Human Understanding.

A. Millar, London.

Kane, R. (1989): „Two Kinds of Incompatibilism.“ Philosophy and Phenomenological Research 50 (2): 219-254.

Kane, R. (2000): „The Dual Regress of Free Will and the Role of Alternative Possibilities." Philosophical Perspectives 14: 57-79.

Mele, A. (2006): Free Will and Luck. Oxford University Press, Oxford.

Moore, G. E. (1912): Ethics. Williams and Norgate, London.

O’Connor, T. (2000a): „Causality, Mind, and Free Will.“ Noûs 34 (14): 105-117.

O’Connor, T. (200ob): Persons and Causes. Oxford University Press, Oxford.

O’Connor, T. (2005): „Freedom With a Human Face.“ Midwest Studies in Philosophy 29 (1): 207-227. 
Pink, T. (2003): Free Will. A Very Short Introduction. Oxford University Press, Oxford.

Pink, T. (2016): Self-Determination. The Ethics of Action. 1. díl. Oxford University Press, Oxford.

Pink, T. (2019): „Freedom, Power and Causation.“ Organon F 26 (1): $1-28$.

Punčochár, V. (2017): „Problém svobodné vůle a logika kontrafaktuálních výroků." Fïlosofický časopis 65 (4): 607-631. Schlick, M. (1939): Problems of Ethics. Prentice Hall, New York. van Inwagen, P. (1975): „The Incompatibility of Free Will and Determinism." Philosophical Studies 27 (3): 185-199. van Inwagen, P. (1983): An Essay on Free Will. Clarendon Press, Oxford.

\begin{abstract}
How it is possible to have free choice in a deterministic world

In this paper I argue against Dvořák's non-deterministic conception of free will developed in his recent book Agent Causation. In particular, I address Dvořák's solution of the problem of randomness, according to which the act of free will is random insofar that it is not governed by deterministic laws, and to this extent it cannot be an object of moral evaluation. I put forward my own conception of free will which contrasts to Dvořák's views and which can be seen as a version of what Dvořák calls the "standard theory". From this point of view, free will is possible in a deterministic world. I further analyze what a choice among alternative possibilities consists in and I argue that one can have control over one's actions even if one does not have control over the past which causally determines these actions. I also explain why I believe - in sharp contrast to Dvořák's conception that a person can be responsible for her actions even if the world is deterministic.
\end{abstract}

Key words: free will, Petr Dvořák, randomness, control, moral responsibility

Punčochář, V. (2021): „Jak je možná svobodná volba v deterministickém světě.“ Filosofie dnes 13 (1): 71-88. Dostupné z www.filosofiednes.ff.uhk.cz. 